\title{
Nationalism and Biographical Transformation: The case of Boudicca
}

\author{
Stephanie Lawson
}

\section{Introduction}

If the purpose of nationalist historiography is to construct a past worthy of the present and future then the role of heroic individuals in the course of key historical events and developments and the construction of suitable biographies to support the narrative is essential to the purpose. Episodes of warfare very often provide the most heroic figures, bolstering national imagery and myth with tales of renown as well as introducing a personal life-story element that not only anchors the individual's biography in a suitable national past but also personalises it in a way that a mere retelling of events cannot. Images of Boudicca, the renowned 'warrior queen' who led an army against the might of imperial Rome in Iron-Age Britain, have been deployed in modern nationalist projects from Victorian times through to more recent times. Not surprisingly, the same images have sometimes been used in feminist struggles for liberation of a different kind.

A suitably stylised iconography - most famously represented by Boudicca's statue at Westminster - is accompanied by a popular biographical representation casting her in the role of leader of her 'nation' against the alien occupier and subjugator. That she ultimately failed matters little. Indeed, to have met death in the course of struggle only enhances the individual's stature. The nationalist romanticisation of Boudicca, however, has not gone unchallenged. Alternative interpretations of her biography depict a violent, vengeful figure who cared as little for most of her fellow Britons as for the occupying Romans. An equally negative version figured prominently in representations of Boudicca in early modern England. These, however, seem to demonstrate more of a discomfort with the challenge to gender roles presented by a female warrior leader in the nation's past than a concern for the way in which she prosecuted her cause. ${ }^{1}$ These differing interpretations highlight the way in which biographies are

1 See, for example, Mikalachki, J. 1998, The Legacy of Boadicea: Gender and nation in early modern England, Routledge, London. 
transformed according to the circumstances of the time and the interests, values and projects involved, thus producing different identities for the figure in question and, by implication, of the nation itself. ${ }^{2}$

In this context, Jonathan Hearn notes that 'identity' is therefore not simply a proxy for biography, but rather also provides a conceptual framework within which the link between biography and the study of nationalism can be better understood. ${ }^{3}$ As suggested above, the way in which Boudicca's life story has been told and retold also reflects aspects of the highly problematic status of heroic women in nationalist myth-making when they step outside the bounds of their 'normal' gender roles and appear to not only act within what is considered to be a largely masculine realm of activity, but also to take leadership positions in that realm. The 'warrior' is very much a masculine ideal embedded in varying cultural contexts. Indeed, it has been argued that war is the most gendered social activity of all, and the strong association of masculinity and war has been expressed in numerous ways across time and space. ${ }^{4}$ It has been promoted in British popular culture, for example, over a considerable period. ${ }^{5}$ One contemporary British commentator suggests that her society is 'very odd' because on those occasions when women do come to power, the only way it can cope with figures such as Boudicca, Elizabeth I and Margaret Thatcher is to make them superhuman. ${ }^{6}$

Female heroism is certainly acceptable, but it has usually been limited to activities associated with the 'feminine arts', nursing and nurturing in particular, as well as sacrificing sons to the cause. A pamphlet produced in the wake of a nineteenth-century war, for example, provides an account of the 'noble sacrifices and exploits of heroic women' who not only 'sent forth their sons' but also themselves displayed, in the face of persecution and danger, a heroism that 'surpassed the charity of Florence Nightingale, and repeated the gentle sacrifices recorded of Mary in the sacred Scriptures'.$^{7}$ These nurturing images also accord with common images of one's country as the 'motherland', easily accommodated by masculinist narratives of the nation. But these are scarcely the images associated with Boudicca, or of most female war leaders produced from time to time in various places, but who are almost always treated as anomalous

2 A detailed study of texts about Boudicca is Williams, C. D. 2009, Boudica and Her Stories: Narrative transformations of a warrior queen, Associated University Presses, Cranbury, UK.

3 Hearn, this volume.

4 Goldstein, J. S. 2003, War and Gender: How gender shapes the war system and vice-versa, Cambridge University Press, Cambridge, p. 10.

5 See, generally, Paris, M. 2000, Warrior Nation: Images of war in British popular culture, 1850-2000, Reaktion Books, London.

6 Miranda Aldouse-Green quoted in Jeffries, S. 2004, 'Return of the queen', Guardian, 30 June, viewed 12 August 2012, <http://www.guardian.co.uk/film/2004/jun/30/features.stuartjeffries>

7 Reproduced in Moore, F. 2004, Women of the War: Their heroism and self-sacrifice, Kessinger Publishing, Whitefish, Mont., p. 18. 
figures transgressing normal war-gender relations. ${ }^{8}$ Another such transgressor was Jeanne D'Arc: the Maid of Orleans; however, despite riding astride with sword in hand, she simultaneously epitomised the purity and sanctity of those endowed with special grace and who could therefore be elevated to Christian sainthood. Interestingly, the English considered her to be a witch because it was simply beyond belief that she could have defeated them without the aid of the devil. ${ }^{9}$

Very little is known with any certainty about Boudicca (sometimes Boudica), better known in an earlier period as Boadicea. As Hearn remarks, such a figure, known only through brief historical accounts recorded by her 'enemies', poses serious limitations on the interpretation of her 'inner life'. ${ }^{10}$ This has scarcely prevented a great many authors, from classic times to the present, from writing extensively not only about her exploits and place in history, but also about her character. ${ }^{11}$ Indeed, it has been noted that legends about Boudicca flourish so richly precisely because we know so little about her actual life, which remains, in Umberto Eco's words, an 'open text' available for endless interpretation. ${ }^{12}$ All these interpretations, of course, say more about their authors and the context from which they write (an observation that must apply as much to the present author) than they do about the person herself, and the discussion that follows shows how changing contexts of national life in Britain impact on the interpretation of the past and the particular figure of Boudicca within it.

There are two classical sources-Tacitus and Cassius Dio-without which knowledge of Boudicca as an individual historical figure would not exist. ${ }^{13}$ Both

8 See, generally, Fraser, A. 2011, Warrior Queens: Boadicea's chariot, [E-book version], Orion Publishing, London.

9 Scott, W. S. 1974, Jeanne D'Arc, George G. Harrap \& Co., London, p. 137.

10 Hearn, this volume.

11 Scholarly analyses, semi-scholarly accounts, novels and juvenile literature abound. In addition to those cited in this article, some of the others published since 2000 alone include: Johnson, M. 2012, Boudicca, Duckworth Press, London; Waite, J. 2011, Boudica's Last Stand: Britain's revolt against Rome, AD 60-61, The History Press, Stroud, UK; McCullough, M. C. 2011, Boudicca, Xulon Press, Maitland, Fla; Fields, N. and Dennis, P. 2011, Boudicca's Rebellion AD 60-61: The Britons rise up against Rome, Osprey Publishing, Oxford; Williams, B. 2010, Boudicca: Great women leaders, Heinemann, London; Bradman, T. 2008, The Story of Boudicca, Wayland, London; Aldhouse-Green, M. 2006, Boudicca Britannia: Rebel, war leader and queen, Pearson-Longman, Harlow, UK; Busby, S. 2006, Boudicca: Warrior queen, Short Books, London; Roesch, J. E. 2006, Boudica: Queen of the Iceni, Robert Hale, London; Ross, S. and Shields, S. 2006, Down with the Romans, Evans Brothers, London; Gold, A. 2005, Warrior Queen: The story of Boudicca, Celtic queen, New American Library, New York; Trow, M. J. 2005, Boudicca: The warrior queen, The History Press, Stroud, UK; Sutcliffe, R. 1979, Song for a Dark Queen, Crowell, New York; Scott, M. 2003, Dreaming the Eagle, Seal Books, Toronto; Hunt, R. 2003, Queen Boudicca's Battle of Britain, Spellmount, Staplehurst, UK; Harrison, A. 2000, Boudicca: Furie of the Celts, Writer's Showcase, Lincoln, Neb. In 2004, it was reported that at least four films about Boudicca were in production or pre-production. See Jeffries, 'Return of the queen'.

12 Jeffries, 'Return of the queen'.

13 The editions consulted for this article are: Tacitus 2010 [1996], The Annals of Imperial Rome, M. Grant (trans. and intro.), Penguin, London; Tacitus 2010, Agricola and Germania, J. B. Rives (trans. and intro.), Penguin, London; Dio Cassius 1987, Roman History, E. Carey (trans.), Harvard University Press, Cambridge, Mass. Citations in the remainder of the article are in the conventional format for classical sources. 
wrote some time after her death, although Tacitus was a near contemporary. Dio wrote a century and a half after the events he depicts and so, apart from the fact that he relies at least partly on Tacitus, he is not considered as authoritative. The basic facts about her exploits as set out in these texts, which include razing three major urban sites to the ground in Roman Britain, are supported by archaeological evidence unearthed in the twentieth century, mainly in the form of a clear destruction layer in each location and which have been dated to the relevant period. ${ }^{14}$ More generally, a reasonable historical knowledge of Iron-Age Britain - and the people now called Celtic - under Roman occupation makes it possible to describe in broad terms the social and political context within which she operated. One commentator says that the best biographers are those 'steeped in the history of particular historical periods and geographical arenas' and this leads in turn to biographies that can explain 'why influential individuals did what they did when they did, and with what exact aims in mind'. ${ }^{15}$ A biography, however, will also be judged according to the issues it speaks to in the present. One reviewer of the Hingley and Unwin text referred to above complains that a disproportionate emphasis is given to 'gender' (which the reviewer places in inverted commas, perhaps to signal a discomfort with the term).${ }^{16}$ Yet it is precisely because Boudicca is female that she has been the subject of so much commentary both in the past and in the present. As one of her best-known biographers has noted, Boudicca presents paradoxes common to the canon of female warrior leaders. Often treated as an exception to the rule of male leadership, the 'warrior queen' may on the one hand excite 'a remarkable outburst of excitement and even awe, sometimes accompanied by admiration and enthusiasm for her cause, beyond the ability of a mere male to arouse'. On the other hand, the emergence of such a figure may be 'accompanied by disgust and fear at her very existence, emotions which would never be aroused by a male leader occupying the same position' ${ }^{17}$ The fact that British society is assumed to have problems - or 'issues' in contemporary parlance - with powerful females is therefore not so odd, but rather a phenomenon common to many societies.

Gender has of course become a critical concern in the humanities and social sciences with respect to both femininities and masculinities and it is therefore scarcely surprising that it should figure prominently in a scholarly analysis of Boudicca. Some of these issues will be further discussed at a later point, but it is time now to turn to a basic account of the events, so far as they are known, which effectively constitute her individual biography.

14 Sealey, P. R. 2004, The Boudican Revolt Against Rome, Shire Publications, Buckinghamshire, UK, pp. 22-3, 32. See also Hingley, R. and Unwin, C. 2005, Boudica: Iron Age Queen, Hambledon \& London, London.

15 Rotberg, Robert I. 2010, ‘Biography and historiography: mutual evidentiary and interdisciplinary considerations', Journal of Interdisciplinary History, vol. XI, no. 3, p. 305.

16 The review in question is by A. T. Fear in Biography (vol. 29, no. 2 [1996], pp. 351-4).

17 Fraser, Warrior Queens, pp. 6-7. 


\section{Life and Times}

Boudicca was born around $30 \mathrm{AD}$, possibly to a prominent family in the region of what is now East Anglia. She was married to Prasutagus, king of the Iceni people native to the region and which was under Roman occupation at the time. Prasutagus and Boudicca were by no means resistance figures. They headed a client kingdom, effectively ruling the Iceni people on behalf of the Roman Empire. This was a common enough arrangement yielding advantages for both sides. When Prasutagus died in AD 60, however, everything changed. He had done a very Roman thing by leaving a written will. Half of his estate was left to the Emperor, Nero, and the other half to his daughters. It is probably safe to assume that he would have preferred to have preserved his family's patrimony in full, but perhaps expected that by leaving half to the Emperor the remainder would be preserved. Alas, if this was indeed the reasoning then it failed dismally in its purpose. The reaction of the Roman Procurator of the time, Catus Decianus, is recorded by Tacitus:

Kingdom and household alike were plundered like prizes of war...As a beginning, his widow Boudicca was flogged and his daughters raped. The Icenian chiefs were deprived of their hereditary estates as if the Romans had been given the whole country. The king's own relatives were treated like slaves. And the humiliated Iceni feared still worse...So they rebelled. ${ }^{18}$

Looking back, it seems that Catus Decianus was not just brutish and nasty in his behaviour, but also irredeemably stupid. After a long period of peace in which Roman interests had thrived, he immediately made implacable enemies of a sizeable tribe in an important area of south-east Britain, and it was to spread further. The outraged queen sought personal revenge, and it was not difficult to garner the support of the Iceni people who had likewise been dispossessed and humiliated. The neighbouring Trinovantes had their own grudges against the Romans. Sometime earlier, the Romans had appropriated the Trinovantian settlement of Camulodulum - present-day Colchester - as a colonia for retired soldiers, and then raised taxes from the local people to pay for building works including a very large temple, which had been dedicated to the deified emperor Claudius. Tacitus reports that the Roman troops encouraged outrages by these settlers, 'since their own way of behaving was the same - and they looked forward to similar licence for themselves'. In addition, 'the temple erected to the divine Claudius was a blatant stronghold of alien rule, and its observances were

18 Tacitus, Annals, vol. XIV, p. 31. 
a pretext to make the natives appointed as its priests drain the whole country dry' ${ }^{19}$ The Trinovantes therefore appeared to need little encouragement to join in what was to become a large-scale revolt.

As luck would have it, the main Roman forces under the command of Suetonius Paulinus were engaged in a campaign against the Druids in their stronghold on the isle of Mona in Anglesey on the other side of the country. This left Camulodunum, which was in any case unfortified, with just a small garrison to defend it and therefore a soft target for the enraged Boudicca and her followers. To cut a long story short, Boudicca and her army wiped out the entire town and its people - Roman and British alike - who at the time numbered around 10 000. The archaeological destruction layer, up to $1 \mathrm{~m}$ deep in some places, shows that Boudicca followed a scorched-earth policy quite literally, the town having been burnt to the ground at very high temperature..$^{20}$ One of the most disturbing elements of the classical accounts, however, is the behaviour of Boudicca's army with respect to women on the other side- both Roman and Briton. Stories of their breasts being sliced off and sown into their mouths and of their bodies being skewered, if true, would rank among the most horrific of atrocities committed against female victims of war. ${ }^{21}$

Having taken revenge within its own territory, Boudicca's army next turned its sights on Londinium on the Thames. According to Tacitus, the town did not rank as a Roman settlement but was rather a prosperous trading port. After dealing out exactly the same treatment to its perceived enemies - a mixture of Roman and local civilians - the army moved on to a third town, Verulamium, near the site of present-day St Albans. This town was occupied mainly by the Catuvellauni people, traditional enemies of the Trinovantes and also more Romanised than many other native tribes. ${ }^{22}$ Archaeological evidence shows, in addition to the destruction layer here, that a number of other smaller native settlements in the surrounding countryside met the same fate. But the rampage was soon to be ended. Suetonius, back with his troops from Anglesey, engaged Boudicca's huge but ill-disciplined and poorly equipped army in a battle that saw the latter's total defeat. Boudicca herself is said to have died from selfadministered poison. Her burial site remains unknown, as does the fate of her daughters. ${ }^{23}$

19 Ibid.

20 Sealey, The Boudican Revolt Against Rome, pp. 22-3.

21 Cassius Dio, Roman History, vol. LXII, p. 62.

22 Some caution is needed in the use of 'Romanisation' since it has multiple meanings and interpretations, not least because it is part of a modernist (and often uncritical) discourse on the nature of empire. This argument is presented in detail in Mattingly, D. 2010, Imperialism, Power and Identity: Experiencing the Roman Empire, Princeton University Press, Princeton, NJ.

23 Cassius Dio provides a similar, albeit briefer, account, probably based partly on that of Tacitus, but differing in many of the finer details and saying almost nothing about the circumstances that instigated the revolt in the first place. Tacitus is considered the more authoritative source. See Overbeck, John C. 1969, 
Thus ended Boudicca's short life of somewhere between 30 and 35 years, and the beginning of nearly 2000 years of contributions to what might be called the Boudicca canon. But before moving on to her representation in this literature, the implications for the relationship between biography and nationalism, and the issues this raises, we need to consider further the social or cultural context of Iron-Age Britain.

The native people of most relevance to the story are those who occupied present-day England and Wales, excluding parts of Yorkshire in the north and Cornwall in the far south-west. These people have been called Celts only since the eighteenth century. The Romans called them Brittones in the north and Brittoni in the south, while, among themselves, the people of the British Isles went only by tribal names. These groups were quite diverse, each evincing distinct cultural practices. In the south-east, including the region of the Iceni, archaeological and other evidence points to the development of a more stratified society in the pre-Roman period, a trend maintained and encouraged by the Romans following conquest of these more 'developed' polities. ${ }^{24}$ As for political unity, it was virtually nonexistent and warfare between the tribes was a commonplace phenomenon. In some regions there were loose confederations of tribes, but beyond this there was certainly nothing resembling a 'national' polity. Tacitus suggests that the Britons once had kings, but had become divided into factions. He further observes that these divisions gave the Romans a decided advantage, for as long as the tribes failed to act in concert, they could more easily be controlled..$^{25}$ The united front presented by the Iceni and Trinovantes, and possibly other smaller groups who joined their ranks opportunistically at the time of the Boudiccan rebellion, was therefore a rare occurrence. One analyst emphasises that there was no such thing as a 'British' identity and that we must guard against seeing the position at the time of the Boudiccan revolt simply in terms of Rome versus Britain. ${ }^{26}$ This is reinforced by detailed historical studies showing that at the time of the invasion of $\mathrm{AD} 43$, there may have been support for Rome among some tribes, especially those who had suffered at the hands of more powerful neighbours and who 'saw Rome as their salvation against their British oppressors' ${ }^{27}$

\footnotetext{
'Tacitus and Dio on Boudica's rebellion', American Journal of Philology, vol. 90, no. 22, pp. 129-45.

24 Hill, J. D. 1995, 'The pre-Roman Iron-Age in Britain and Ireland (ca. 800 BC to 100 AD): an overview', Journal of Prehistory, vol. 9, no. 1, p. 82.

25 Tacitus, Agricola and Germania, vol. I, p. 12.

26 Niblett, R. 2006, 'Images of Boudica', Britannia, vol. XXXVII, p. 490.

27 Webster, G. 1995, 'The Celtic Britons under Rome', in M. J. Green (ed.), Celtic World, Routledge, London, p. 629. For a more critical analysis from a post-colonial perspective, which suggests that the tendency to interpret native cooperation with the Romans may be exaggerated in the interests of presenting a more positive and indeed pro-Roman view, see Mattingly, D. 2006, An Imperial Possession, Britain in the Roman Empire, Penguin, London.
} 
Of particular interest for the present discussion are certain cultural elements that served to distinguish certain practices and values of what are now called the British Celts of the Iron Age from Romans, or from Romanised people, especially with respect to the status of females. There is evidence for at least some of the tribes that female leadership was a cultural norm, something that contrasted very markedly with Roman attitudes to women. Tacitus remarks that Boudicca's regal status was typical of Britons, who he said made no distinction between the sexes when it came to matters of royal succession. ${ }^{28}$ In both the Histories ${ }^{29}$ and the Annals, ${ }^{30}$ Tacitus tells of another Queen, Cartimandua, leader of a loose confederation of the Brigantes tribes of northern England, whose leading deity was the goddess Brigantia. Cartimandua's realm had become another client kingdom in Roman Britain, one which remained in alliance with the Romans and which in fact assisted in their battles with other, less cooperative tribes, including those of King Caratacus, the best-known male leader of the period resisting Roman rule. ${ }^{31}$ With respect to female leadership generally, one source says that queenship was an institution peculiar to Britain in this period, and was not evident among European Celts. Its absence among the latter makes it unlikely that the phenomenon was imported with Celts moving from the Continent into the British Isles, and therefore may have originated with preCeltic inhabitants of Britain. ${ }^{32}$

As for the Romans, they had their goddesses, but female leadership among mortals was not to be tolerated and the fact that female leaders appeared among the Britons only confirmed them as uncivilised primitives. Furthermore, it seems to have 'feminised' Britons. Tacitus's accounts of both the battle in Anglesey against the Druids, in which native females participated (although evidently not as leaders), and the subsequent battle against Boudicca's forces tend to assimilate native forces with women. According to historian Michael Roberts, Tacitus depicts native Britons as relying on 'emotion' and 'display', which are equated with femininity, while the Romans show manly discipline and rationality. ${ }^{33}$ This is very familiar imagery in gender analysis. Roberts goes on to note, however, that the formulation of Boudicca's cause is particularly

\footnotetext{
28 Tacitus, Agricola and Germania, vol. I.

29 Ibid., vol. III.

30 Ibid., vol. XII.

31 For a recent account of Cartimandua, which includes an assessment of Roman attitudes to female leadership as slightly more forgiving in the case of a loyal client, see Howarth, N. 2009, Cartimandua: Queen of the Brigantes, The History Press, Stroud, UK. It is interesting to note that only one book on Cartimandua has ever been produced, in contrast with the dozens written about Boudicca.

32 Bulst, C. M. 1961, 'The revolt of Queen Boudica in A. D. 60', Historia: Zeitschrift für Alte Geschichte, vol. 10, no. 4, pp. 496-509.

33 Roberts, M. 1988, 'The revolt of Boudica (Tacitus Annals 14-29-39) and the assertion of libertas in Neroian Rome', American Journal of Philology, vol. 109, p. 123.
} 
subversive because 'it associates libertas with the female, and servitium with the male' ${ }^{34}$ In the further interpretation of Boudicca, and her place in British national historiography, gender continued to play a key role.

\section{Interpreting Boudicca}

It has been noted that the works of both Tacitus and Cassius Dio are the only surviving accounts produced relatively close to the time of the rebellion. Without them, no knowledge of Boudicca at all, and only a very hazy idea of some of the major events in the history of Roman Britain, would be available. These works themselves only just survived, having been preserved in monastic libraries after the fall of the Roman Empire. The only other possible independent source appears in a sixth-century text, De Excidio Britanniae, authored by the pro-Roman Saint Gildas, where mention is made of a 'treacherous lioness' in connection with the murder of some Roman governors. It is possible that Boudicca's exploits may have survived to that point through oral tradition. The text does not mention her by name, but at least one of Boudicca's biographers assumes the words of Gildas to be a direct reference to her, ${ }^{35}$ although another source suggests that the 'treacherous lioness' was Britain itself. ${ }^{36}$ The Venerable Bede's eighth-century Historia Ecclesiastia mentions two towns being sacked, but again there is no direct mention of Boudicca. Even so, some contemporary authors claim that this is a reference to Boudicca. ${ }^{37}$

It wasn't until the Renaissance that the works of Tacitus and Cassius Dio became available and Boudicca was given a firm place in British history. And it is from this time onwards that her biography becomes entangled in varying approaches to nationalism. Although her name appears in the works of many historians and literary figures over the past five centuries, we have space here for just a few of those which best exemplify her shifting status through ongoing interpretation, which in turn reflects changing attitudes to gender and its entanglement with the nationalist enterprise. The most important periods in question are those more or less encompassing the reigns of Elizabeth I and James I and, later, Queen

\footnotetext{
34 Ibid., p. 127. For further analysis of Roman attitudes to sex and gender, and broader comparisons of the 'feminisation' of 'lower races' in later political and social thought as well as the associations with power, see Mattingly, Imperialism, Power and Identity, especially Ch. 4.

35 Collingridge, V. 2006, Boudica, Ebury Press, London, p. 307.

36 It has been suggested, however, that the 'treacherous lioness' was Britain itself, and not the Icenian Queen. See Thompson, E. A. 1979, 'Gildas and the history of Britain', Britannia, vol. 10, p. 204.

37 See Matza, A. (ed.) 2010, Boudica: Historical commentaries, poetry and plays, Xlibris Corp, Bloomington, Ind.
} 
Victoria. It has been argued that in the former, early modern period, images of Boudicca took shape for the political and social needs of the day, and that these 'set the tone for future depictions of the nation's greatest female patriot' ${ }^{38}$

Her first appearance of real substance, clearly based on Tacitus, is in Hector Böece's The History and Chronicles of Scotland, published in 1526, sometime before Elizabeth was to take the throne. In a bid to boost the importance of Scotland, the story of Boudicca's exploits is relocated northwards. Böece also mistakenly calls her 'Voada', while a daughter is given the name 'Vodicia', thus creating two characters. The errors of naming aside - a common occurrence in many accounts of her exploits through the ages - gender is an issue for Böece, who composes a speech for his leading character: 'Had I been born a man...I might not have suffered so many cruel and intolerable injuries...these Romans, so valiant against women...may soon know what valour ladies may do when extreme danger occurs...I shall fight foremost in the battle with 5,000 armed ladies.' ${ }^{39}$

Böece's interpretation is considered sympathetic to his female characters, who, though forceful, are also honourable in avenging the serious wrongs inflicted on them. ${ }^{40}$ Another account, which now appears squarely within the Elizabethan period, again presents two separate female characters: Voadicia and Bunduica. This is the narrative provided by a Florentine scholar, Petruccio Ubaldini, who spent much of his adult life in England and was associated with the Elizabethan Court. A work on The Lives of the Noble Ladies of the Kingdom of England and Scotland, published in 1591, includes an account of Boudicca in which, again, a sympathetic note is struck, with honour rather than shame being emphasised and certain moral lessons drawn from righteous resistance to oppression and cruelty as vengeance. ${ }^{41}$ Here we may note also that biography in this period was 'highly esteemed for its didactic value', ${ }^{42}$ a tradition no doubt adapted from the much admired classical authors, especially Plutarch. ${ }^{43}$

This was preceded, although only just, by Raphael Holinshed's Chronicles, a massive work of history, which was published between 1577 and 1587. Holingshed's narrative, while perhaps not intentionally setting up a 'national project' as such, is nonetheless said to 'be characterised by a set of rhetorical figures and thematic paradigms that establish the national, royal, chivalrous and

38 Frénée-Hutchins, S. 2009, 'The cultural and ideological significance of representations of Boudica during the reigns of Elizabeth I and James I', Unpublished PhD thesis, Universities of Exeter and Orléans, pp. 9-10.

39 Quoted ibid., p. 21.

40 Hingley and Unwin, Boudica, p. 118.

41 See Dudley, D. R. and Webster, G. 1962, The Rebellion of Boudicca, Routledge \& Kegan Paul, London, pp.

119-20. See also Matza, Boudica, p. 24.

42 Dudley and Webster, The Rebellion of Boudicca, p. 120.

43 See Plutarch 1992, The Lives of the Noble Grecians and Romans, J. Dryden and A. H. Clough (trans), Modern Library, New York. 
heroic ideals that define a state, its monarch, its leaders, and the political role of the common people'. ${ }^{44}$ It is interesting that in this context Holinshed evinces strong elements of sympathy with the character of Boudicca. But this was also the period in which, according to one analyst, anxiety over the nation's descent from a collection of barbaric tribes became apparent in a 'conflicted nationalism' that required "both affirmation and denial of the "native" in projects of national reconstruction' ${ }^{45}$ Boudicca is said to have become problematic in more than one way, for she not only embodied native savagery, but also subverted the natural order of things in terms of gender hierarchy. With respect to Holinshed, the analysis sees him subscribing to a wholly masculinist view of his subject, portraying the Boudiccan revolt and accompanying atrocities in terms of a 'grotesquely feminized savagery' — an interpretation that, it is said, resonated strongly with early modern misogyny. ${ }^{46}$

A very different interpretation of Holinshed, however, sees him representing 'Voadicea' as 'a spokeswoman of national self-consciousness and political freedoms'. Holinshed's text also provides a long speech ostensibly delivered by Boudicca on the eve of the final battle on the subject of 'ancient liberty' (a speech derived loosely from Cassius Dio's, which borrowed in turn from a shorter speech composed by Tacitus). ${ }^{47}$ It was common of course for classical authors to pen such speeches, partly because their texts were designed to be read out loud, and the spirited delivery of an ostensibly authentic oration delivered by a key character enhanced dramatic effect. The tradition continued with subsequent writers composing speeches that tended to reflect their own concerns and interests. In any event, it is clear from Holinshed's version of her speech that he did indeed endow Boudicca's character with a love of liberty and a willingness to sacrifice her life in the cause of freedom from an alien oppressor:

I doo suppose...that there is no man here but dooth understand how much libertie and freedome is to be preferred before thraldom and bondage... How much is it more commendable to lose our lives in defense of our countrie, than to carie about not so much as our heads toll free, but dailie oppressed and laden with innumerable extractions $?^{48}$

Having delivered the speech on her behalf, Holinshed goes on to report Boudicca's final march against the Romans 'to whom she giveth a shameful and bloudie overthrow without anie motion of mercie, dredfull examples of the Britains crueltie indifferentlie executed without exception of age or sex' ${ }^{49}$

44 Djordjevic, I. 1998, Holinshed's Nation: Ideals, memories and practical policy in the chronicles, Ashgate, Farnham, UK, p. 10.

45 Mikalachki, The Legacy of Boadicea, p. 9.

46 Ibid., p. 15.

47 Patterson, A. 1994, Reading Holinshed's Chronicles, University of Chicago Press, Chicago, p. 104.

48 Reproduced in Matza, Boudica, p. 63.

49 Ibid., p. 66. 
Whether we are entitled to read this latter comment, and other references to the slaughter that Holinshed drew from Cassius Dio, as an example of early modern misogyny is open to question. That Holinshed depicts her as a defender of the nation's liberty, however, is beyond doubt. It is perhaps no coincidence that this positive interpretation, and those of others noted above, was offered during a period in which a female wore the British Crown, for the first time. With Elizabeth I on the throne it seems likely that some more flexible approaches to gender roles were required. But as we have seen, Böece had already provided a more or less sympathetic interpretation of Boudicca well before Elizabeth's ascent, and so not all such accounts can be attributed to a desire to make a female monarch more acceptable.

When James I came to the throne after 45 years of female leadership, however, he seemed 'eager to impress his own identity onto the British landscape'. This meant that 'references to strong female leaders, particularly unmarried ones, fell out of favour as women were re-consigned to the home and family' and the name Boudicca became 'a by-word for political and social subversion' ${ }^{50}$ A play by John Fletcher produced between 1609 and 1614, during the reign of James I, depicts Boudicca as a nasty witch surrounded by Druids, apparently to please the king. ${ }^{51}$ Hingley and Unwin note that although Boudicca is also portrayed as courageous, Fletcher generally characterises her as rash and headstrong, the implication being that as a woman she was incapable of dealing wisely in matters of politics and warfare. The initial victories of her army are credited to Caratacus, whose lines in the play take Boudicca to task for playing the "woman fool' commanded by the devil. ${ }^{52}$ The play was evidently a great success and was adapted and reproduced throughout the following three centuries.

John Milton's A History of Britain, published later in the century, re-examines the classical sources and produces an account of Boudicca's exploits based largely on these. Milton declines to repeat the set speeches placed in Boudicca's mouth, or to compose one of his own:

I affect not set speeches in a history, unless known for certain to have been spoken in effect as they are written... and to invent such, though eloquently (as some historians have done,) is an abuse of posterity, raising, in them that read, other conceptions of those times and persons that were true. ${ }^{53}$

50 Frenee-Hutchins, The cultural and ideological significance of representations of Boudica, pp. 11-12.

51 Johnson, P. 2007, Heroes: From Alexander the Great and Julius Caesar to Churchill and de Gaulle, Harper Collins, London, p. 53.

52 Hingley and Unwin, Boudica, p. 131.

53 Milton, J. 1818, The History of Britain: That part especially, now called England; From the first traditional beginning, continued to the Norman Conquest, R. Wilks, London, p. 55. 
But Milton does refer to the set speeches in the classical texts, and their repetition by earlier chroniclers, when it comes to describing the prelude to the final battle. He first comments on the folly that doubtless made 'the serious Romans smile at, as a sure token of prospering that day: a woman also was their commander in chief'. He continues:

For Boadicea and her daughters ride about in a chariot, telling the tall champions, as a great encouragement, that it was usual for women to be their leaders. A deal of other fondness they put into her mouth, not worth recital; how she was lashed, how her daughters were handled, things worthier silence, reticence, and a veil, than for a woman to repeat, as done to her own person, or to hear repeated to a host of men. ${ }^{54}$

With references to Britain's earlier chroniclers, Milton goes on to say that in repeating and elaborating the set speeches, they were 'hoping to embellish... their history with the strangeness of our manners, not caring, in the meanwhile, to brand us with the rankest note of barbarism, as if in Britain women were men, and men women' ${ }^{55}$ It is noteworthy that Milton, on the one hand, makes a case for good historiography by rejecting the rhetoric of set speeches, which may distort the original context, but on the other appears to suggest that historical references to female leadership should be elided, thus distorting the context in another way.

Writing on the general problem of establishing suitable narratives of national origins in early modern England, Jodi Mikalachki notes that in the works of writers such as Milton, the 'absence of a native classical past on which to found the glories of the modern nation' is made even worse by the fact that 'powerful women loomed large' - a fact that simply emphasised the primitive savagery of the early Britons. Thus Mikalachki proposes that 'powerful and rebellious females in native historiography threatened the establishment of a stable, masculine identity for the early modern nation' ${ }^{56}$ Whether we agree with this interpretation, it is at the very least evident that there were diverse approaches to Boudicca in the early modern period generally, both positive and negative, some of which illustrate the anxieties and contradictions provoked by the challenges presented by prominent female figures in the formation of an acceptable national history and identity. ${ }^{57}$ At an even deeper level, the control of women then, as in many societies now, was seen as essential to social order, ${ }^{58}$ and clearly Boudicca was out of control.

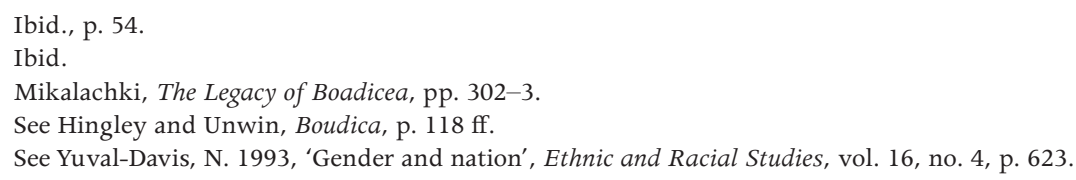


Moving from the early modern to the Victorian era, we see that although there were certain continuities in thought, there were also some significant changes in Boudicca's status. One commentator notes that although authors in previous periods saw Boudicca 'as an object of scorn and admiration in almost equal measure', she had not generated sufficient public interest to elevate her to heroic status until the latter part of the nineteenth century. ${ }^{59}$ Another writes that this period saw the emergence of a belief 'that Britain's unwritten constitution was of immemorial antiquity' and that Boudicca had played a part in its foundation. This marked a major turning point in the transformation of the Boudicca narrative and her establishment as a heroine of the British nation. ${ }^{60}$ Alfred Lord Tennyson's 1859 poem 'Boadicea' links her exploits specifically with the glories of an early British nation, although references to the 'wild' and 'fierce' nature of the chief character and her followers maintain an image of savagery, as established in the first verse:

While about the shore of Mona those Neroian legionaries Burnt and broke the grove and altar of the Druid and Druidess, Far in the East Boadicea, standing loftily charioted, Mad and Maddening all that heard her in her fierce volubility, Girt by half the tribes in Britain, near the colony Camulodune, Yell'd and shriek'd between her daughters o'er a wild confederacy. ${ }^{61}$

Meanwhile, work on a monumental sculpture had begun in 1856, although it wasn't finally placed in its present position on the Embankment near Westminster Bridge until 1902, where it inspired both nationalist and imperialist sentiment. This was, after all, the heyday of the British Empire. The inscription, from a prescient 1780 poem by William Cowper called 'Boadicea: An Ode', reads: 'Regions that Caesar never knew, thy posterity shall sway.' ${ }^{62}$ Thus Boudicca represents, at one and the same time, a form of anti-colonial nationalism and the glories of contemporary imperial Britain. Both are celebrated, evidently without fear of contradiction or anachronism, as representing the magnificent character of the British nation. Here is where one of the hypocrisies of nationalism is most clearly manifest. Imperialism is not a bad thing - unless you (or your ancestors) are the subject nation. Yet, at the same time, admiration for the Roman Empire persisted in scholarly approaches to historiography, with one analysis published in 1906 proclaiming the Roman Empire to be the first great imperial experiment, 'which rose above the methods of brute force or mere well-devised bureaucracy

59 Vandrei, M. n.d., 'Who will be a coward when a woman leads? Boudica and the Victorian female hero', Unpublished paper, viewed 10 April 2012, <http://www.essex.ac.uk/.../Vandrei\%20-\%20Who_Will_Be_a_ Coward.pdf>

60 Johnson, Heroes, p. 55.

61 Tennyson, Baron A. 1870, The Poetical Works of Alfred Tennyson, Poet Laureate, Harper \& Brothers, New York, p. 206.

62 Cowper, W. 1835, 'Boadicea: An Ode', in John S. Memes (ed.), The Works of William Cowper, [Second edn], Fraser \& Co., Edinburgh, p. 358. 
[and] made a genuine effort to unite liberty and empire', ${ }^{63}$ thus inviting comparisons with a flourishing British Empire legitimated by its own version of what it means to liberate and civilise.

But there is another equally telling irony in the placement of the statue in the heart of London. Geographer Peter J. Taylor points out that 'on her route to historical glory, Boudicca razed London to the ground and slaughtered its residents. London is honouring its destroyer!' The presence of the statue, he says, thus represents the 'victory of one history over another' ${ }^{64}$ Another commentator notes that Boudicca's statue stands as if she was 'defending the very embodiment of the kind of Establishment she tried so hard to destroy' ${ }^{65}$ She is also commemorated in Colchester, scene of her most violent confrontation, with a stained-glass window in the town hall: a sombre head-and-shoulders representation with the figure holding a spear. ${ }^{66}$ Another statue of Boudicca, which shows quite a different kind of character, is on display in Cardiff's civic hall: Boudicca poses in soft, flowing robes, with arms around her daughters in a protective maternal embrace ${ }^{67}$ Apart from this very different, much gentler representation, the location of the work appears to claim Boudicca for a Welsh national tradition based on the closer link of the Welsh to the ancient Celts. ${ }^{68}$

Another paradox emerges in the fact that early feminists in general and suffragettes in particular found inspiration in the figure of a woman whose army dealt out particularly nasty treatment to 'enemy' women, both Roman and Briton. A woman arrested during the course of a suffragette protest gave her name as 'Boadicea'. ${ }^{69}$ Also available as part of the paraphernalia of the suffragette movement were Boadicea badges, which were worn along with the movement's colours of green, white and purple. ${ }^{70}$ A portrait of Christabel Pankhurst, a leading suffragette of the early twentieth century, appeared in London's Bystander magazine on 1 April 1908, bearing the legend 'A Boadicea of Politics'.$^{71}$ While she may have provided some inspiration for feminists in the

63 E. Fiddes, quoted in Mattingly, Imperialism, Power and Identity, p. 10.

64 Taylor, P. J. 2007, 'Problematizing city/state relations: towards a geohistorical understanding of contemporary globalization', GaWC Research Bulletin, vol. 32, no. 2, pp. 133-4.

65 Webster, G. 1978, Boudica: The British revolt against Rome, Routledge, London, p. 14.

66 Both images may be viewed at the web site of 'Culture 24 ': $<$ http://www.culture $24 . o r g . u k / h i s t o r y \% 20$ $\% 26 \% 20$ heritage/war $\% 20 \% 26 \% 20$ conflict/pre-20th\%20century $\% 20$ conflict/tra22669> (viewed 10 April 2012).

67 See <http://www.welshicons.org.uk/html/statue_of_boudicca.php> (viewed 10 April 2012).

68 One work of note in this respect is a storybook: Rutherford, A. 1999, Boadicea and Her Sisters: Women of Wales, Rhwymbooks, Cambridge, Mass.

69 Van Wingerden, S. A. 1999, The Women's Suffragette Movement in Britain, 1866-1928, Palgrave Macmillan, Basingstoke, UK, p. 150.

70 Ibid., p. 95.

71 See National Portrait Gallery n.d., Chasing the suffragettes: a Boadicea of politics, viewed 6 April 2012, $<$ http://www.npg.org.uk/research/new-research-on-the-collection/chasing-the-suffragettes-a-boadicea-ofpolitics.php> 
past, Boudicca presents rather too many contradictions to be really useful in feminist iconography and no longer appears anywhere on the Fawcett Society web site. ${ }^{72}$

It is interesting to note that the suffragette movement brought out into the open some grossly negative attitudes to woman, which resonated with some of those of earlier periods. One critic of the movement opined that figures such as Boadicea, along with Amazons, Lydians, Brunhilde and the Valkyries, were relics of 'primordial dominance' and appeared only among 'savage tribes that still retain their primitive customs' ${ }^{73}$ And, referring back to Elizabeth I, the same commentator was positively venomous in his assessment of her reign:

Her voice was coarse and masculine when it did not shriek with rage. She could outswear a fishwife... She cheated all contemporary diplomacy and won the palm of a lying epoch as its liar paramount... when the Spanish Armada went down she grumbled at the cost of the fleet that sank it...in her mean and stingy way... She deliberately turned frivolity into a statecraft; hawked, hunted and danced in the midst of perils that the people might not see them...meanwhile the Nation prayed for her death... as every other nation has done and will do for the woman who tries to rule it. ${ }^{74}$

But how was this to be reconciled with the glorious reign of a female monarch that had ended just a few years before? Quite simply, through sheer hypocrisy. Of Victoria, he claimed that during her half-century or so on the throne:

She wore the crown without meddling in the affairs of State. In the realm her husband was her subject, but at the fireside he was her sovereign...Court pomps and revels could not beguile her from the higher home-throne where she proved her transcendent queenliness by a womanly demeanor worth more than a thousand times to her people than Elizabethan statecraft. ${ }^{75}$

Attitudes to female leadership on the part of British men such as these clearly not only represented a continuity from early modern times - at least after Elizabeth I- but also evinced a mode of thought on gender issues more compatible with that of the Romans than their own ancient forebears. Indeed, the author quoted above, and others like him who rejected the aims of the suffragette movement and opposed greater equality for females more generally, displayed a positive

\footnotetext{
72 The Fawcett Society is named for Millicent Garrett Fawcett, a nineteenth-century activist, and campaigns for equality between women and men in all spheres of life. See $<$ http://www.fawcettsociety.org.uk/index. asp?PageID $=37>$

73 Holland, R. A. 1909, 'The suffragette', Sewanee Review, vol. 17, no. 3, p. 276

74 Ibid., pp. 287-8.

75 Ibid., p. 288.
} 
distaste, if not shame, with respect to the primitive, uncivilised nature of the native inhabitants of Iron-Age Britain. As for Victoria herself, we know she opposed the suffragette movement and cared little for the rights of other women, believing their primary role to be that of mother and wife subordinate to their husbands. ${ }^{76}$

Even so, it was during her reign - and perhaps despite Victoria herself - that significant advances were made with respect to women's rights, although voting rights remained elusive for the time being. This was also the period in which the Boudiccan monument was commissioned and installed by the Houses of Parliament, another contradiction apparently accommodated without great difficulty. Martha Vandrei writes that Boudicca's elevation to status of national heroine actually came not through her promotion by women activists, but was in fact due to powerful men with royal contacts who placed her in that position. ${ }^{77}$ The incorporation of heroic female leaders in the national/imperial narrative clearly did not bother these men-and indeed they must be seen as having encouraged it.

Boudicca's status as a national figure of heroic character consolidated throughout the earlier part of the twentieth century, as exemplified in a 1928 feature film ${ }^{78}$ and by the works of such authors as Lewis Spence and C. H. Abrahall in which she is hailed as the first national patriot striking a blow for British freedom. ${ }^{79}$ This is almost certainly linked to the changing status of women in general. World War I had seen the active participation of women in a range of occupations, and in 1918 they were finally enfranchised in the United Kingdom. In World War II, women's participation extended further, and the young Princess Elizabeth, heir to the throne, insisted on serving as a mechanic. Gender roles were not exactly turned on their head, but these developments paved the way for much more thoroughgoing social change in the second half of the century and to a nationalism more receptive to female heroes.

In mid-century, however, the conservative Winston Churchill's History of the English-Speaking Peoples still displayed a somewhat ambivalent attitude to the nature of the Boudiccan revolt and what it meant for British history. He certainly saw the ancient Britons as primitive in relation to the 'higher civilisation' achieved by Rome, even though he believed the latter to be both rudimentary and flawed. Of the revolt itself, he wrote that it was

\footnotetext{
76 This illustrates the importance of not treating women (or men) as a homogeneous category. See YuvalDavis, 'Gender and nation', p. 630.

77 Vandrei, 'Who will be a coward when a woman leads?', p. 7.

78 See <http://www.imdb.com/title/tt0018713/> (viewed 10 April 2012).

79 Spence, L. 1937, Boadicea, Warrior Queen of the Britons, R. Hale, London; Abrahall, C. H. 1949, Boadicea, Queen of the Iceni, George G. Harrap \& Company, London.
} 
probably the most horrible episode which our Island has known. We see the crude and corrupt beginning of a higher civilization blotted out by the ferocious uprising of the native tribes. Still, it is the primary right of men to die and kill for the land they live in, and to punish with exceptional severity all members of their own race who have warmed their hands at the invader's earth. ${ }^{80}$

Interest in Roman Britain generally at the time of Churchill, however, was not strong and it was not until the 1960s that the field began to attract more interest from historians, classicists, archaeologists and others. ${ }^{81}$ But it was the emergence of Britain's first female prime minister, and especially the outbreak of the Falklands War, that gave the figure of Boudicca more prominence. Linkages with Margaret Thatcher were inevitable, but most were superficial, appearing simply as trite headlines in daily papers. With respect to imagery, cartoons of Thatcher - one following victory in the Falklands War and the other on polling day $1987^{82}$ - are clearly associated with female success in leadership. At the time of the Falklands War, it was of course Thatcher who took the decision to deploy military force, while Queen Elizabeth, as Antonia Fraser points out, was simply the reigning monarch. ${ }^{83}$ It might also be said that the personality of Thatcher, otherwise known as the 'Iron Lady', was always more likely to attract comparisons - whether favourable or unfavourable - with the Iron-Age queen. Still, it is noteworthy that Elizabeth II, the monarch and symbol of (and for) the British nation for the past six decades, does not appear to have attracted a single comparison with the figure so often held up as Britain's first female monarch.

As for the present, Boudicca's statue remains in place on the Embankment next to the Houses of Parliament from where she continues to inspire elements of British nationalism. Standard accounts now generally present her as 'one of Britain's greatest heroines... a freedom fighter who rebelled against the Roman government...Queen to the Celts and truly...one of history's most fiercest and passionate warrior queens' ${ }^{84}$ This is certainly the image that dominates in contemporary popular culture - mainly through films and novels but the occasional song as well. ${ }^{85}$ Not surprisingly, Boudicca also has a presence on web sites associated with far-right xenophobic nationalism, although not to a significant extent.

\footnotetext{
80 Churchill, Sir W. S. 1965, A History of the English-Speaking Peoples, Dodd, Mead \& Company, London, p. 27.

81 Todd, M. 2004, 'Introduction', in M. Todd (ed.), A Companion to Roman Britain, Blackwell, Oxford, p. xx.

82 Reproduced in Frénée-Hutchins, The cultural and ideological significance of representations of Boudica,

pp. 290-1.

83 Fraser, Warrior Queens, p. 5.

84 See <http://heroinesofhistory.wikispaces.com/Boudica $>$ (viewed 2 April 2012).

85 See Collingridge, Boudica, pp. 397-402.
} 


\section{Conclusion}

The life and times of Boudicca are perhaps as well known as they ever will be, although archaeologists and others will no doubt build incrementally on the evidence available to date, filling in more detail of what is known of the period. And it is not impossible that something will emerge in the future that throws more light on her personal history. Those issues aside, this discussion has been as much concerned with illustrating how the biography of a particular individual constitutes (as Hearn suggests in this volume) an element within a wider analysis of national identity. With respect to the last question, we may well ask whether the limits of her biographical interpretation have been reached. She has already been cast in roles as diverse as mother heroine of the British nation on the one hand, and as a disgraceful figure plumbing the depths of primitive savagery and thereby bringing shame on the nation's past on the other. These contradictory images are in part a reflection of the difficulty that nationalisms often have in accommodating female figures who do not conform to conventional gender images and who challenge hegemonic masculinities. ${ }^{86}$ Beyond the particular difficulties that a fighting female presents - to some forms of feminist analysis as much as to traditional masculinist approaches - any serious student of nationalism knows only too well that historical figures can be made to play different roles according to the circumstances of the time and the interests and values involved. We live in an era of diverse and often conflicting and contradictory approaches to feminism and the study of gender as well as of identity, biography, nationalism and the history of empire. For these reasons, acts of interpretation producing varying identities for Boudicca, and emerging on the basis of a scant but provocative life story, are likely to remain ongoing projects in narratives of the British nation and its history.

86 For an analysis of the latter, see Nagel, J. 1998, 'Masculinity and nationalism: gender and sexuality in the making of nations', Ethnic and Racial Studies, vol. 21, no. 2, pp. 242-69. See also, Yuval-Davis, N. 1997, Gender and Nation, Routledge, London. 